\title{
Comparación de los componentes de la literatura de perseverancia en dos poetas importantes de la era Ghaznavi: Sanayi Y Masoud Sa'd Salman
}

\section{Comparison of the Components of Perservance Literature in two Important Poets of Ghaznavi era: Sanayi and Masoud Sa'd Salman}

\author{
Elham Naimi $^{1 \mathrm{a}}$, Reza Ashrafzadeh ${ }^{2}$
}

Islamic Azad University, Mashhad Branch, Mashhad, Iran ${ }^{12}$

iD Orcid ID: https://orcid.org/0000-0002-8664-3394 ${ }^{1}$

(iD) Orcid ID: https://orcid.org/0000-0002-5392-9273²

Recibido: 13 de marzo de 2020

Aceptado: 10 de agosto de 2020

\begin{abstract}
Resumen
A lo largo de la historia de la literatura persa, ha habido poetas que han alimentado los tesoros literarios persas con su pluma capaz. En ese sentido, este artículo examina y compara específicamente los poemas de la sostenibilidad de los dos innovadores y dueños del estilo en la era Qaznavid. Por un lado, Sanayi estableció una especie de poesía social y crítica. La poesía gnóstica y Qalandar con sus letras y refrescó la doctrina religiosa con su Masnavis y expresó cuestiones religiosas en forma de historias. Por otro lado, los temas de la literatura de sostenibilidad son claramente evidentes en todas sus formas poéticas. Temas como la lucha contra la opresión y la pobreza, la invitación a una paz duradera y la promoción de la ética religiosa. Masood Sa'd es uno de los innovadores de élite de la era Ghaznavi, y su Habsiyeh (encarcelamiento), Shahrashoub y sus encantamientos muestran el genio de su poesía. Su utilización de los componentes de la sostenibilidad es muy significativa, especialmente en su encarcelamiento, y en otros tipos de poesía, tiene menos. El presente estudio trató de investigar estos componentes con respecto a las limitaciones de la estructura del artículo desde una perspectiva integral después de un estudio cuidadoso de los trabajos de estos dos poetas y lograr los ejemplos sobresalientes de literatura de sostenibilidad.
\end{abstract}

Palabras clave: Sanayi, literatura de perseverancia, Masoud Sa'd Salman, literatura iraní, Irán, literatura mundial.

\begin{abstract}
Throughout the history of Persian literature, there have been poets who have fueled the Persian literary treasures with their capable pen. In that sense, this article specifically examines and compares the poems of the sustainability of the two innovative and owners of style in Qaznavid era. On the one hand, Sanayi established a kind of social and critical poetry. Gnostic and Qalandar poetry with its lyrics and He freshened the religious doctrine with his Masnavis and expressed religious issues in the form of stories. On the other hand, the issues of sustainability literature are clearly evident in all of its poetic forms. Topics such as the fight against oppression
\end{abstract}


and poverty, the invitation to lasting peace and the promotion of religious ethics. Masood Sa'd is one of the elite innovators of the Ghaznavi era, and his Habsiyeh (imprisonment), Shahrashoub, and his enchants show the genius of his poetry. His utilization of the components of sustainability is very significant especially in his imprisonment, and in other types of poetry, he has less. The present study tried to investigate these components regarding the limitations of article structure from a comprehensive perspective after careful study of the works of these two poets and acheiving the outstanding examples of sustainability literature.

Keywords: Sanayi, perseverance literature, Masoud Sa'ad Salman, Iranian literature, Iran, World Literature.

\section{Introduction}

Persian poetry from the second half of the fifth century until the beginning of the seventh century has undergone through various transformations from every respect. In this era, new meanings enter the poetry. On the one hand, eulogy continues in its previous form and on the other hand, effective and sweet Sufi couplets and prison poems are written. The content of odes and romances is extended and varied and the scope of the description becomes hugely expanded. Sanaei in Sufi couplets and Masoud Sa'd in prison poetry surpass the others. Of course, factors of resistance literature in the poems of these two great poets are manifested in a form and we will discuss them in this essay in a particular way.

The works of Sanaei and Masoud Sa'd have high potentiality for research in the domain of different innovations and new phrases. Masoud is a poet who has written elegies and eulogies. In his poems written in prison, as it is noted in the outlines of the four essays, "he has managed to be successful in presentation of his emotions to the reader" (Moein, 1987). Prison poetry for him is a form for retelling his own mental states and one can find all elements and factors of resistance literature in the prison poems of Masoud. The words of Sanaei has the color of innovation and he has presented the notions of monotheism, investigation, advice, criticism and resistance in them. In the present study, we seek to merely deal with the aspect of resistance literature in his poems.

As to the introduction of the categories of resistance literature, one can refer to "Letter of Resistance" by Ahmad Amiri Khorasan and "Analytic History of Resistance Poetry" by Basiri, (2009). Mosffa (1956) in a research has studied the innovations of the poets from the point of view of the content and secondary aspects of elegy up to the fifth century of Hijri. Zarqani et al. (2015) have conducted a study entitled "Role of Sanaei in Evolution of Persian Elegy" and showed that Sanaei and Nasir Khosrow are the turning points in the evolution of the Persian elegy.

In this context, reflection and research in the domain of resistance poetry and literature particularly in the present era is of an undeniable necessity. As to Masoud Sa'd, some studies have been conducted regarding his heartbreaking poems in prison and the motions that lie in 
them and their factors of resistance literature. It seems that the discussion of resistance literature is less colorful on the works of Sanaei than what this great poet deserves in reality. In the present essay, we have sought to comparatively discuss these features in a detailed form.

\section{Methodology}

The present study's research method is library research and description and analysis. In this study, many of the Persian bibliographies, books of the literature's history by Iranian thinkers and Iran's researchers as well as the research articles have been studied and evaluated. Meanwhile respecting the notions of all the researchers, the present article's authors intend to posit and investigate all the theories and hypotheses and scientifically criticize them through adopting a strategic approach and aiming at an applied goal thereby to draw a roadmap for the future. It is evident that the research on this issue is vast and in need of extensive research; it is hoped that the present study can set the ground for the other researchers to deal with this issue and offer scientific and executive solutions for the growth and development of Persian literature amongst the people, particularly the young generations, and present a research first of its type.

\section{Discussion}

Here we introduce the resistance literature and the scope of the advantage that these two poets have taken of it in their poems.

\section{Resistance literature}

"Resistance literature is a type of committed literature that is created by people and intellectual pioneers of the society against those who threaten their material and spiritual life. Its goal is prevention from deviation in the literature and its gradual flourishing and evolution" (Basiri, 2009).

One can state that this type of literature includes all works that have emerged in the specific social and political conditions of authoritarianism that dominates the country. their voice is echoed not only in its own time rather in all times. It can also serve as a resort for expression of truth and a model for pro-justice movements of other poets and writers.

\section{Factors of resistance literature}

The researchers of this area have considered some elements as the factors of resistance literature including homeland, resistance against the enemy, peace, friendship, battle against oppression and poverty, prevalence of religious ethics and distribution of ritual values and etc.

\section{Political and Social Conditions of the Era of Masoud Sa'd and Sanaei Ghaznavi}

Political and Social Conditions of Masoud Sa'd. In the couplets that have remained from 
Masoud, one can find the footprint of habits and ethics of the politicians and the court staff of the first era of Ghaznawis. Vilification, revenge, radicalism and violation, were among the vicious features of many politicians in this era.

Social and Political Conditions of the Era of Sanaei. Sanaei after becoming famous, turned to the court of Ghaznawis and in an era of his life, his mystical thoughts became strong and in some way, he experienced the sense of separation from the world. Although Ghaznawi court was ready to receive him, he preferred to choose the seclusion for further spiritual contemplations and initiations. Nasir Al Din Abu Rashid Abd Al Jalil Qazwini Razi, in his "Al Naqs", mentions the name of Sanaei as the greatest Shia poet (Safa, 1987).

\section{Factors of Resistance Literature in the Poems of Masoud Sa'd and Sanaei Ghaznawi}

We will continue to assay the elements of the resistance literature in a clear fashion in the poems of these two poets.

Resistance before the Enemy. Resistance is a very extensive notion and sometimes it takes a negative bent. Resistance is not merely in the sense of direct confrontation and resilience before the enemy. Sometimes the enemy is repressed through the enumeration of one's own virtues and the poet in an indirect way and in an implicit form proceeds to destroy the enemy and his evil plans.

\section{Resistance before the Enemy in the Works of Masoud Sa'd}

In one poem, Masoud expresses the reason of his imprisonment as follows:

"Once I am tired of the plague of Lahore/

Once I am exposed to the slander of Khorasan" (Yasami, 1983).

Sometimes he considers himself to be pure and by these poems he seeks to suppress the enemy:

"Allah knows that I am like the wolf that never tore Joseph/ They are accusing me for something that I have not done" (Ibrahim Tabar, 2017).

Even in the dark corner of the prison, Masoud does not stop bragging:

"O Lahore! Shame on you! How could you exist without me? / How could you be bright without the shining sun?"

He addresses his enemies as deceiving and base:

"You have been separated from

the wise and caring friends/ 
How would you deal with

the villain enemies?"

(Ibrahim Tabar, 2017).

The descriptions of Masoud bespeak of a lifelong agony and wound that have its root inside. He creates the sense of sympathy and belonging in the reader. In his eulogies, he complains of the rule of the oppressors and dictators.

\section{Resistance before the Enemy in the Poems of Sanaei}

Sanaei based on his unique mystical musings, as to the resistance before the enemy, believes that the main enemy of man is his own soul and he continuously warns against the possible deceptions of carnal soul.

"If you do not annihilate

your carnal soul/

you would never

touch the eternity"

(Amiri Khorasani, 2008).

He thinks of this world as a prison. There are three prisons that put chains on human reason and the five senses are the soldiers and spies of the worldly reign. He presents a very lively picture of this prison.

"You have imprisoned the reason

in the cage of body/

with three chains of

envy and jealousy"

(Ibrahim Tabar, 2017).

\section{Battle against oppression and poverty}

The literature that deal with the social issues, criticizes the status quo and struggles for changing it has always existed and will continue to exist. The resistance literature depicts one of the particular manifestations of social criticism. It opens an aperture from the present towards the future. It takes the present undesirable condition in which oppression and poverty surge as its point of departure in order to move towards the desirable future full of justice and equality in wealth although this future seems to be impossible. In a world torn by chaos and insecurity in the present, we need a belief to revive the spirit of battle against oppression again and trigger an internal revolution. 
Masoud Sa'd is one of the distinguished poets who has pioneered the battle with the oppression and this can be seen in every single word and verse of this poet. The tone of the prison poems of Masoud is romantic, intimate and passive and if one can find an epic like picture in his poetry, it is for the characters and elements that are before him and put pressure on him. He complains of the oppression that has been leveled against him.

"Just like the inferno and the Lord/

I have a house and a door keeper"

(Yasami, 1983).

We see an intellectual and expressional contradiction in the poetry of Masoud. This contradiction has its origin in two different situations of his life, i.e. once he was protected by the King and he lived a luxurious life and later he becomes miserable and he has the nostalgia of those time.

"I am revolting against the King/

I have stopped believing in God"

(Amiri Khorasani, 2008).

The first verse of the elegy entitled "In Praise of Sultan Masoud after His Hunt", he praises the justice and religiosity of the King.

"O' You are the judge of

the world for truth/

You are just King who

protects the religion"

(Amiri Khorasani, 2008).

Masoud provides all moral prescriptions and recommendations of the battle against oppression in a very subtle and shrewd way and in the form of different praises.

"People resort to you for justice/

You are the proud of the country"

(Jamshidian \& Norouzpur, 2010).

Contrary to Sanaei, Masoud does not have colorful Sufi and mystical concerns. It was Sanaei who let this type of thinking to enter the Persian poetry in sixth century and later this turned to a type of literary tradition. But this issue is not the case with the poems of Masoud. He takes advantage of natural description and a rich language and by combining these two elements creates rich praises. In praise of "Seif Al Dawlah Mahmoud” he states: 
"You are supported by reason,

beneficence and generosity/

You have no supporter

among the Kings"

(Jamshidian \& Norouzpur, 2010).

The scope of description in the poems of Masoud becomes so extended that he takes advantage of these elements with higher frequency for expression of the notions of resistance.

"Your polish on the blade of art/

has cleaned the taint of oppression

from the world"

(Amiri Khorasani, 2008).

\section{Battle with Oppression in the Works of Sanaei}

Sanaei has very strong religious emotions. For example, he believes that Ibn Muljam killed Imam Ali because he had fallen in love with a cursed woman who wanted the blood of Imam as her dowry.

"If you have a lion's heart for dealing with your affair/

The cursed woman's dowry is the blood of Imam Ali" (Ashrafzadeh, 2008).

Finally, after the murder of Imam Ali, he reveals the secrets and introduces Muawyah as the one had designed this plot.

"It was Muawyah who

ordered me to do this/

I did it and it makes

no good lamenting now"

(Jamshidian \& Norouzpur, 2010).

Here Sanaei expresses his passion and love for Imam and his curse for the enemies of Imam Ali and we can consider such poems in the era of Sanaei among the resistance literature.

"If someone's heart is void

of Imam's love/

It is not a heart rather it is

just an organ" 
(Afrasyabpur, 2009).

The Karbala event is of a specific manifestation in the poems of Sanaei. This poet is in love with the Prophet's household and considers Imam Hossein the manifestation of resistance before the infidelity and atheism and distortion of religion.

"God bless his friends/

and down with his enemies"

(Afrasyabpur, 2009).

Sanaei relates the Karbala event by indication of the details of the names of persons, spaces, states, factors that pave the ground for this event, the formation of this uprising and so on and so forth.

"The path of shame is closed/

the word and promise of

religion are broken"

(Afrasyabpur, 2009).

Shia Muslims wherever see an oppression against Imam Ali and his household, they feel obliged to curse those who are involved in that oppression, because they believe that oppressing Imam is equivalent to infidelity.

"Those whose leaders are Omar and 'Aas/

Or the cursed Yazid is their leader/

They deserve to be punished and cursed/

Because they have chosen the wrong path,

and act wrongly and their religion is evil" (Sajjadi, 2000).

Hakim Sanaei clearly suggests that only being a Shia can lead one to the eternal life:

"Be a devoted Shia Muslim so that

you can touch eternity/

Everything but religion is

death and grief"

(Sajjadi, 2000).

In addition to the Shia beliefs and creeds, we encounter unique stories in his Hadiqah and the issue of the battle against oppression is vividly discussed in the works of Sanaei, The story of the oppressor and the oppressed: 
"A child addressed an unfair rival/

and told him that you are just deception and crime/

in your shop of deception/

the Satan has found a good place for itself"

(Sajjadi, 2000).

Like many committed poets, Sanaei is concerned of people and he pursues the thoughts of resistance in all places of his works. Sanaei seeks to cast light on the weakness of people and society. He openly expresses his spicy criticisms. He praises the religion and no doubt, one of the key points that are underlined in the religion is the social justice and the battle against oppression and poverty.

"Although you are Qobad and Parviz in this world/

You may have been emerged from the dust of a dog"

(Afrasyabpur, 2009).

Through his praises, Sanaei offers certain advices to the one who is praised concerning the observation of justice:

"Religion and the state depend on your blade/

infidelity and atheism are in dread of you"

(Shafei Kadkani, 1997).

"No one's neck is chopped out of revenge/

Like Ali this would not be done but as religion orders".

In his eulogy of Amir Jalal Al Dawlah Abu Al Fath Dawlatshah, Sanaei invites him to good deed, avoidance of the hasty judgements, justice expansion and making people happy.

"Extending the hand of

generosity and friendship/

is other than opening and closing".

He relates a story in which Sultan Mahmoud sends a message to the King of Roma and asks tax otherwise Roma will be destroyed to the ground. He provides the envoy with a number of answers that he would give when the Romans quarrel with him.

"He is a servant's son and 
an oppressor/

I have no dispute with you in this/

But in the lands under the control of this man/

No one would oppress anyone but him"

(Afrasyabpur, 2009).

\section{Pacifism}

Pacifism is one of the other factors of the resistance literature and poetry serves as an effective tool for expression of this meaning. The poetry addresses the general public and it has to use their language so that the communication and the transmission of the message to take place in a simpler way. Man, by his nature is avoiding war and clash and he is naturally seeking after a peaceful relationship.

The works of two poets discussed in this article have many ups and downs. Particularly, Hakim Sanaei who has experienced completely different periods during his life and in his mystical poems which are one of the turning points of the mystical discussions, he reminds the subject of pacifism and interaction with others through different doctrines.

\section{Pacifism in the Works of Sanaei}

One of the most controversial issues that can be seen in the works of Sanaei is the issue of monotheism of Satan as to which Sufis have different stances. Many Sufis referred to the issue of trial and devotion as regards the disobedience of Satan. In other words, although God ordered the angels to prostrate before Adam, but His intention was that the Satan not to do it. Therefore, the order of prostration is the surface of the story but God wanted something else.

My heart carried his love/

my heart was the nest for the Phoenix of love/

he put his trap in my path/

Adam in the middle of that circle was the seed/

He wanted to make me the sign of curse/

He did what he wanted and the

terrestrial man was an excuse/

I read in the slate that one would be cursed/

I thought it was not me"

(Fruzanfar, 1996).

The precise examination of the above elegy suggests that Sanaei has considered Satan to deserve pity based on the spirit of toleration that is shared by the Sufis. It is needless to say that his present stance as regards Satan is also applied to others and he treats people with the spirit 
of friendship and toleration. He hopes that everyone will see divine compassion even Satan. He believes that the key feature of a King is compassion.

"If the King is familiar with compassion/

How could an audacious man be a King/

the audacious would destroy the land/

from his audacity he would militarize the land/

no one saw any prosperity in the audacity/

no one found peace and happiness"

(Ashrafzadeh, 2008).

It is needless to say that audacity in this context refers to boldness, lack of place and futurism

\section{Pacifism in the Works of Masoud Sa'd}

Eulogies of Masoul are full of the themes of pacifism and peace and invitation to happiness and joy. This is something which is different from his spirit in the prison poems.

"I will not describe my conditions further/

I am satisfied for anything worse"

(Yasami, 1983).

Even in the elegies through which he wants to prove his innocence, Masoud does not mention any particular person's name and attributes his imprisonment to the destiny. Sometimes he considers himself to be completely innocent.

"God knows I am the wolf

that didn't eat Joseph/

They are just accusing me of

something I have not done"

(Sajjadi, 2000).

In another place, he believes that his intelligence is one of the reasons of his imprisonment but, again, he does this with a special shrewdness:

"I would attribute it to myself like a gem/

I am not like the ash that arises from the fire".

Sometime he just refers to the "plague of Lahore" 
or the slander of Khorsan but he refuses to elaborate the issue further.

"I am once tired of the plague of Lahore/

and some other time I am exposed to

the slander of Khorasan"

(Afrasyabpur, 2009).

\section{Prevalence of Religious Ethics}

Religious literature is the literature that deals with religious categories and there are attraction and spirituality in it. Religious literature has numerous branches and many of the eulogies and beautiful exegetical texts lie under it. In religious literature, we are encountered with two elements of religion and literature. In other words, one can take advantage of the potentiality of the superior language of the literature for promotion of the religious notions and the texts of the committed poets are full of these themes

\section{Promotion of Religious Ethics in the Works of Sanaei}

The most important aspect of distinction of Sanaei can be sought for in elegies whose discourse is Sufi-mystical. He has succeeded to introduce the spiritual experiences of the mystics of second, third, fourth and fifth centuries into the traditional structures of the Persian poetry and create the ascetic poetry based on parables.

"Do not reside the body and soul as

this is lower and the other is higher/

put your step outside both,

be neither here nor there"

(Fruzanfar, 1996).

The following two elegies are also advice from the beginning to the end. They can be categorized as examples of the discourse of advice. The opening verses of these elegies are as follows:

"O Sanaei! When you will have an

open eye in the love game/

if you do not head back to the path of

eye from the heart's mood".

"Shame on you! The veil tearing

the veils that looks at us/

Please no longer tear our veil

before every fool" 
(Shafei Kadkani, 1997).

To promote the religious ethics, Sanaei believes that the first step is the knowledge of God. He states that the knowledge of God requires internal enlightenment and it should be associated with a spark.

"The word of the man of reason

through inferences/

Is the gem of religion and his mind

is the diamond"

(Ashrafzadeh, 2008).

This path does not have any other guide but the Imams and the Prophet.

"When you praised God/

Then you have to proceed to

praise the Prophet".

One of the most distinguished manifestations of the religious ethics is separating oneself from the worldly attachment. The roots of the worldliness should be eradicated and one should resign himself to Divine Will. Sanaei, by metaphor, notes that worldly property and position and bending knee before the worldly leaders are hidden paganism. One should cultivate his spirit, body and soul with the knowledge and reason. The points of weakness should be reduced and the points of strength, i.e. reason and spirit, must be strengthened.

Our review of the works of Sanaei clearly shows that his mind and thoughts have changed. We can see that he has moved from the stage of praising to the stage of social character where he no longer wants to be a servant of other creatures like him rather he is only focused on the creator of all creatures. He intended to convey his thoughts and beliefs to the society through his poems. He wanted them to be practical and guide the scholars and men of knowledge in every age. He has spoken of all cultural, literary, religious, economic, cultural and ethical cases and even as to the formation of family and child education. Let's read part of his religious poems:

"Keeping oneself committed to

the religious precepts is better/

Drinking wine is better than eating

the donated properties".

"Be thankful of the time/ 
that you have been born into Islam".

\section{Promotion of Religious Ethics in the Works of Masoud Sa'd}

Almost half of the Divan of the poet is devoted to the explanation of his troubles during his imprisonment. Masoud has a set of poems in praise of the statesmen, lords and the King. Anyway, the issue of promotion of religious ethics in the works of Masoud is less colorful in the works of Sanaei given his biography. Here one can refer to few cases of this:

\section{A) Confession of sin, mistake and repentance:}

"I am ashamed of what I have done/ I know other path but repentance" " (Yasami, 1983).

B) In Praise of Honesty:

Masoud praises Hossein Tabib as follows:

"We have to be honest/ God knows the hidden and manifest".

Insistence on Liberty:

“The liberated man who seeks after good fame in poetry/ He should not ask for a price from the people just like the servants".

"Do not be self-growing weed in the desert in every cold and warm climate of the world/ Be like a liberated cedar before every hardship".

C) Invitation to patience:

"From the Lord Mowafaq Mansour Ibn Saeed/ The one who has a shirt of patience and a cloak from generosity".

D) Promotion of Generosity:

"There is no limit for his generosity/ He is born in mountain and a son of sea" (Shafei Kadkani, 1997).

"My hands are full of money thanks to your generosity/ My body is full of precious clothes due to your state of mind" (Shafei Kadkani, 1997).

\section{Conclusion}

The words of every poet have their origin in his way of thinking and thoughts. The poems of Sanaei and Masoud Sa'd are also emanated from their mind and thought. If Sanaei sets mysticism the main theme of his poetry, in his personal life he is a man of mysticism, ethics and moral advice and in one sense, one can see all specific factors of the resistance literature particularly the promotion of the religious ethics in his poetry. In his prison poems, Masoud Sa'd laments of the earth and time. He has undergone through numerous hardships and agonies in his life and this has caused the resistance to turn to a comprehensive substance in his poetry not merely a current among other currents. Sanaei and Masoud Sa'd are both "resisters" and have written the rhetorical poetry. These champions of resistance suffer from the pains of others 
and their internal crisis emerges in their poetry and the present study sought to present part of these features.

In current essay, it became clear that the factor of battle with oppression and poverty are more colorful in the works of Masoud as compared to the works of Sanaei while Sanaei in his discussion of the promotion of religious ethics has acted stronger than Masoud Sa'd. Although the features of resistance literature are not the only distinguished strand of this texture, rather this axis is related to others in a network form. However, the ideas of these two great poets are directly related with their society and all these strands join together and convey a type of complication and intertwinement to the reader.

\section{References}

Afrasyabpur, A. (2009). A Commentary of Sanaei's Hadiqah Al Haqiqah va Sharia Al Tariqah, Tehran, Iran: Erfan Press.

Amiri, K. A. (2008). Letter of Resistance. Foundation for Preservation of Works and Distribution of Values of Holy Defense.

Ashrafzadeh, R. (2008). Fire Making Water (Selected Collection of Hadiqah Al Haqiqah of Sanaei Ghaznavi), Tehran, Iran: Jami Press.

Basiri, M. (2009), Analytic History of Resistance Poetry in Persian Literature. Kerman: Bahonar University of Kerman Press.

Fruzanfar, B. (1996). Divan of Hakim Sanaei Ghaznavi. Tehran, Iran: Negah Press.

Ibrahim, T. I. (2017), An Analysis of Resistance Literature in the Poems of Simin Behbahani. Journal of Resistance Literature, 16(3): 1-20.

Jamshidian, H. \& Norouzpur, L. (2010), Innovations of Nasir Khosrow in the Tradition of Persian Elegies. History of Literature, 66(3): 71-91.

Moein, M. (1987). A Critical Edition of Four Essays by Nizami Aruzi. Tehran, Irán: Amir Kabir Press.

Mosffa, M. (1956), Edited Version of Majma Al Safha, Tehran, Irán: Mousavi Press.

Safa, Z. (1987), History of Literature in Iran, Tehran, Iran: Amir Kabir.

Sajjadi Z. (2000), Sanaei Ghaznavi (Selected Poems), Tehran, Iran: Zavar Press.

Shafei Kadkani, M. (1997), Lashes of Spiritual Initiation, Tehran, Iran: Agah Press.

Yasami, R. (1983), A Critical Edition of Divan of Masoud Sa'd, Tehran, Iran: Amir Kabir.

Zarqani, M., Gharib, M., y Mahdawi M. (2015), Role of Sanaei in Evolution of Persian Elegy, Journal of Literature Rose Garden, 7(4): 49-76. 